\title{
John Banville and His Romantic Quest
}

\author{
Wang Jing \\ School of Foreign Languages, Soochow University, Jiangsu, China
}

Copyright $\bigcirc 2018$ by authors, all rights reserved. Authors agree that this article remains permanently open access under the terms of the Creative Commons Attribution License 4.0 International License

\begin{abstract}
John Banville, one of Ireland's most serious and gifted writers, shares the belief of modernist writers that the modern society alienates mankind through its chaos, madness and sterility, but denies the fatalist idea that this society is hopelessly doomed. He, therefore, pursues a romantic quest in his fiction by resorting to nostalgia, nature and imagination. This thesis will study Banville's fiction from a Romantic perspective, aiming to reveal how Banvill returns to Romanticism and pursues a romantic quest. By examining his various books, this thesis will discuss how Banville looks for a spiritual home by writing about nostalgia, nature and highlighting imagination. It concludes that the utopian world created by Banville for his protagonists, cannot solve all problems in reality. However, it provides an ideal, a belief towards a sublimate life, which helps mankind bravely face the real world and provides hope. Banville imagines a better world in his fiction; and if imagined, this world might in time actually come to be.
\end{abstract}

Keywords Nostalgia, Nature; Imagination, John Banville

\section{Introduction}

John Banville, author of the Man Booker Prize-winning book The Sea (2005), has been widely known for being referential, ambiguous and complex in his fiction. He is "one of Ireland's most serious and gifted writers"[1], to quote John O'Donohue, Irish Minister for Arts, and is thought to be "one of the most important writers now at work in English", "a key thinker in fiction"[2] by London Review of Books. Thanks to his poetic intensity and profound themes, Banville was honored with numerous awards, including the Franz Kafka Prize, the Irish PEN Award for outstanding Achievement in Irish Literature and the Prince of Austria's Award, Spain's most important literary prize.

With a writing career that started back in 1970, Banville is frequently categorized as a European postmodernist. Most critics focus on the modernistic and post-modernistic features in his writing, but neglect his relation to or tendency towards the Romantic tradition. In the following sections, this thesis will study Banville's fiction from a Romantic perspective, aiming to reveal how Banvill returns to Romanticism and pursues a romantic quest. By examining his various books, this thesis will discuss how Banville looks for a spiritual home by writing about nostalgia, nature and highlighting imagination.

\section{Nostalgia}

Banville favors writing about the past. In most of his books, readers may be deeply touched by a yearning for the past, an intense and overwhelming emotion called nostalgia. And it is nostalgia that Banville appeals to as a means of spiritual salvation. The term nostalgia is made up of two Greek roots: nostos (returning home) and algia (pain), describing a longing for the past, often in an idealized form. Described first as a mental condition in a medical report of 1787 about a Welsh solder suffering from homesickness, the term comes to be a recurring theme in Irish Romanticism.

From the eighteenth century on, nostalgia seems to be connected with the desire to return home. During the Irish Famine (1740-1741) and the Great Famine (1845-1852), millions of Irish people emigrated to other countries. After the Famine, there emerged many Irish writers and the descendants of those emigrants who produced sets of nostalgic novels, expressing emigrants' desire to return home, including Thomas Moran, Lisa Carey, Katherine Weber, Alice McDermott, and Mary Gordon. At the same time, homeland was articulated in terms of the nation state, and nostalgia began to take on its associations with nationalism. W. B. Yeats in many of his poems expressed his interest in the past historical beauty and his yearning for the past. Today, nostalgia is seen as a key component of Romantic culture and has captured scholars' attention worldwide.

\subsection{Nostalgic Protagonists}

Readers interested in Banville's books should not ignore the fact that they are definitely not character-driven. In his 
fictional world, Banville creates an array of alienated protagonists, extremely sensitive and of an artistic temperament, suffering from spiritual confusion and distortion. Most of them are either falling apart under life's pressure or in the throes of some crisis. Since the present life is too much for Banville's protagonists, it is quite natural for them to cast their eyes onto the past. These protagonists can return to a tiniest thing long ago in their childhood in retrospect; they can also remember vividly a stranger who once appeared in their life but turn a blind eye towards their loved ones, if there are any; they may be hurt by a smile from strangers but hurt their families even more by silence and neglect; they are marionettes, entangled in the exploration of the relationship between creation and reality. They prefer to live in the past rather than the present because of the unbearable failure they must face in the real world.

In Eclipse, the characterization of Alexander Cleave leaves a deep impression on all his readers while in The Sea, Max Morden is a more typical Banvillean character. The following paragraphs will present a specific analysis of their romantic and nostalgic characteristics.

As many other Banville characters, Cleave and Morden are both romantic and sensitive middle-aged men who undergo troubles in their life and return to their childhood home. For Cleave, the biggest trouble he suffers is his failure onstage. At the peak of his career, he is suddenly faced with a desperate collapse: he is struck speechless on stage, which is described as "a giant statue toppling off its pedestal and smashing into rubble on the stage."'[4] As the fall is unbearable, Cleave escapes back to his childhood house, keeping a distance from the harsh and brutal reality. So, at the beginning of Eclipse, Cleave tells his wife his dream in which he was a child and returned to his childhood home. The response of his wife is a little bit ironical: "Of course; you never left here, that's the truth."[3] This mocking reply actually points out the vital characteristic of Cleave: he always lives in his memory and the past. While living back in the old house, he sinks into a painful struggle between two worlds: old and new, past and present. In retrospection, Cleave can find a shelter from the hurt brought by the failure in the real world.

For Morden in The Sea, not only has he recently experienced the trauma of losing his wife, but another tragedy from the past keeps haunting him. The two traumas both prove to be hard to deal with and he cannot rid himself of these chronic disturbances of the mind. "The past beats inside me like a second heart." [4] So he comes to live in a guesthouse-cum-nursing home in the same resort where he spent the summer years ago. His return gradually yields the objects of his nostalgia. Throughout the novel, his recollection of the holiday or the Grace family especially, together with his memory of the life with his wife, intermingles with his present life back on the beach. And as a result, the narration alternates between the past and the present while the former one acts a vital performance. The holiday he once spent in a coastal town has a great impact on him and it is so memorable that he almost spends his entire life reminiscing it. In his memory, he recollects his encounter with the Grace family, his childhood love for Mrs. Grace, his transition of love from Mrs. Grace to her daughter Chloe and the death of the twins of the family, etc. Through his narration, an image of a sorrowful old man, tracing back his childhood in great difficulties, is presented in front of readers.

Cleave and Morden are typical Banvillean characters, showing an inclination towards the past or the old world in that "the ideal that is not being lived now is projected into the past."'[5] And just as Morden admits that "we sought escape from an intolerable present in the only tense possible, the past, that is, the faraway past"[4], all Banvillean characters seek to find a shelter in nostalgia, which provides a temporary and transitory peace for them.

\subsection{Writing Myths}

Myths are sacred stories with settings mostly in a timeless past before recorded history. While recording past glories, myths also offer constructive interpretations of the past for the present. When novelists use myths in fiction, they can invoke a form of nostalgia. In The Sea, Banville refers to this recorded past when Morden states "I was a keen reader and had a fair knowledge of the Greek myths."[4] In his works, Banville uses the nostalgia invoked by myths to imply that his protagonists have a spiritual home.

The most significant myth in Banville's books is the story of Odysseus. In Homer's epic poem The Odyssey, Odysseus is depicted as a hero determined to return home. After the Trojan War, Odysseus travels home with numerous slaves and much treasure. Unfortunately, he enrages the God Poseidon, and therefore encounters numerous perils as he sails home. After many hardships and much frustration in a voyage that takes ten years, Odysseus finally returns home and reunites with his wife and sons. "Going home" is Odyssey's most prominent theme.

In Banville's works, the myth of Odysseus's "return home" is also a recurring motif. In Eclipse and The Sea, both Cleave and Morden have a strong desire to return home. In Eclipse, after Cleave's failure onstage, he believes there is a voice deep in his mind calling him. "The house itself it was that drew me back, sent out its secret summoners to bid me come...home, I was going to say."[3] Therefore, he drives home alone in winter twilight. On the road, an animal appears in front of the car, sharp teeth and eyes flashing. It is hard to identify the animal; it looks like "just some wild unknown thing".[3] Though Cleave is terrified, something inside him does not allow him to give up and he continues his journey. Despite many difficulties, and his wife's scolding and insults, he returns home only to find the house is occupied by two intruders. 
In The Sea, Morden also returns to the coastal beach where he once spent a boyhood summer, sharing the holiday with the Grace family. This beach is a kind of spiritual home to him. Morden explains to the readers the reason he returns to the beach: "a dream it was that drew me back." [4] In the dream, Morden is determined to travel somewhere, going home it seems, although he does not know exactly what or where home might be. It involves hours of walking but he does not mind, for this is a journey of surpassing but inexplicable importance, one that he must make and is bound to complete. Like Cleave, Morden, despite his daughter's opposition, finally returns home.

These two Banvillean characters share almost the same destiny as Odysseus, and so they symbolize Odysseus. The parallel with Odysseus's courage and perseverance makes Cleave and Morden's arduous journeys more visual and vivid. Odysseus's perseverance is not merely about returning to his palace, but rather a return to a "spiritual home". The parallel indicates that Cleave and Morden's returns are also a search for their spiritual home, an ideal past.

Banville's novels include many myths other than the Odyssey, including that of Sisyphus. In Greek mythology, Sisyphus is cursed to roll a huge boulder up a hill, only to watch it roll down again. He must repeat this throughout eternity. Sisyphus's ordeal symbolizes failure and agony. In Banville's books, his characters are all striving to live, to understand the world, to understand their relationships with the people around them. Though they are destined to always fail, they never give up and start over and over again. From his first book, Long Lankin, Banville writes about various failures: the failure to get along with family members is common to nearly every character in Banville's novels; the failure for Doctor Copernicus and Kepler to understand life and the universe; the failure of career, such as Cleave in Eclipse; the failure to escape past memories, such as Morden in The Sea. Banville creates a never-ending series of failures, which reminds readers of Sisyphus. This image creates a feeling of romance and nostalgic sorrow in his characters.

Banville also uses myths more casually in his books. In Eclipse, Cleave compares his parents to Baucis and Philemon[3], a poor but peaceful couple in Greek mythology. This leaves a deep impression on readers about the relationship between his parents. He also describes his daughter as Minerva[3], the Roman name of the Greek goddess Athena, which matches the unyielding and combative nature of his daughter, Cass. He regards Dora, a secret lover in his youth, as Muse, the goddess who inspires artists. This comparison shows how Dora supported Cleave, and her importance to him. In The Sea, Banville refers to a range of myths. Morden compares the Grace family to Gods as they are superior to him in social status. He thinks of Mrs. Grace as a goddess, believing that she is perfect, and he compares Mr. Grace to Poseidon, because he is strong and full of ability. He compares himself to a lyreless
Orpheus. While Orpheus is a god of songs and is good at playing the harp, a lyreless Orpheus symbolizes a man of failure, lost and wandering once he has lost his greatest talent.

The nostalgic nature of myths fits with the atmosphere of Banville's meditation books. In Mefisto, the name implies the story of Faust, which is one of the most enduring myths of western culture. It tells of a man who makes a deal with the devil, but he can never be happy or satisfied despite all the devil's best efforts, and if one day he is satisfied, he will be immediately damned. In Banville's novel, the Faust figure is named Felix, who is a genius at telling sly jokes.

The way Banville's protagonists are linked with myths, fits with the desire of his characters to immerse themselves in the past. By writing myths and nostalgic characters, Banville creates a nostalgic world which protects his characters from the pain of the real world.

\section{Nature}

In trying to answer the questions concerning human existence in modern society, Banville turns to the past for inspiration. However, the solace that nostalgia brings is momentary since man cannot live in the past forever. Besides, when good memories clash with harsh reality, the pain turns out to be more unbearable. Realizing that nostalgia is definitely not man's spiritual home, Banville turns to nature, where man can be saved from life's chaos and absurdity.

Nature, almost a synonym of Romanticism, is a predominant Romantic theme at the time of the Industrial Revolution. For many Romantic poets, nature is more than just a backdrop or setting for human activity. Rather, it is mysterious and has a healing and inspiring power. Some Romantics look to nature as the source of solace, inspiration and self-discovery. Therefore, one of the defining characteristics of the Romantic Movement is its enduring engagement with nature.

Ireland has been world-famous for its beautiful scenery, which has always been described as spectacular, awesome, eye-catching, splendid, etc. Surrounded by the North Atlantic to the west, the Irish Sea to the east, Ireland has a coast line longer than $1448 \mathrm{~km}$. The whole country has steep cliffs, blue oceans and pristine beaches everywhere. Besides, due to its mild temperature, Ireland, the Emerald Isle, is green all year round. Living in such a beautiful country, Banville definitely shares with Romantics a sincere love of nature and expresses it fully in his works.

In Birchwood, the most haunting symbol, an image that holds a fascination for the young Gabriel Godkin is the eponymous birchwood itself:

I liked it (the birchwood) there, and when, surfeited on the fetid air of the lower wood, I sought the sunlight above the hill, there on a high ridge, to lift my spirit, was the eponymous patch of birches, restlessly gay little tress 
which sang in summer, and in winter winds rattle together their bare branches as delicate as lace. [6]

This animistic image of nature appeals to the young Gabriel tremendously as it pleases his sense of fantasy and mystery. He, therefore, turns away from the world's crude realities and tries to seek solace in the bosom of nature, in whose embraces he has found peace and happiness, whose beauty and responsiveness calm him. Joseph McMinn, Professor of Anglo-Irish Studies at the University of Ulster, once commented on Gabriel's love of nature, saying "the image of the wood may be read as a reflected image of the subconscious, dream-like mind, seeking comfort in the unreal", and the wood allows Gabriel to "relieve some primitive, almost forbidden desire."[7] Later in the novel, a traveling circus takes Gabriel back to nature, where he finally finds his spiritual home.

In The Sea, Max Morden is depicted as a bird-lover. He admits, "I was quite a bird enthusiast as a boy."[4] He loves birds and often takes time to observe a robin perched on a branch. By looking at the robin, he feels closer to nature and life's disorder stops haunting him. His love of nature brings him peace in his otherwise chaotic and busy life.

In Banville's works, the most important and recurring image is the sea. Back in ancient times, the sea was adored as a mysterious and strong companion of human beings. Hence, there are the lord of the sea, Poseidon and goddess of the sea, Thetis. In western literature, the image of the sea is often connected with life, the cradle of life and the ongoing pursuit of life. However, as an uncontrollable universal power, it is dangerous and mysterious as well, symbolizing life's uncertainty and the inevitability of death. Hence, the sea is a symbol of both life and death.

The image of the sea keeps appearing in Banville's fiction. In Eclipse, Cleave likes walking at the seaside, facing the ever-changing sea while mediating over the meaning of life.

"The morning was still, under a seamless white sky. There was a full tide, and the surface of the water, taut and burnished like billowing silk, seemed higher than the land, and on the point of spilling over. The waves were hardly waves at all, more a wrinkle running the edges of a sluggishly swaying vast bowl of water." [3]

Mesmeric and magical, the sea soothes Cleave's mind and comforts him.

In his most renowned book, The Sea, Banville depicted an awe-inspiring image of the sea at the very beginning of the novel: "All morning under a milky sky the waters in the bay had swelled and swelled, rising to unheard-of heights, the small waves creeping over perched sand that for years had known no wetting save for rain and lapping the very bases of the dunes." [4] The mystery and the power of the sea are shown vividly to readers. Besides, the swelling water, dunes, the rusted hulk of the freighter at the end of the bay and the seabirds hinted at desolation and sadness.
Later, readers come to know that what happened in Max's childhood took place mostly beside the sea: Max came to the seaside resort for a summer vacation; he played with the Grace family on the beach; the twins of the Grace family drowned in the sea and Anna, Max's wife, spent her last few days beside the sea. The sea is a witness of Max's happiness and sorrows. It swallows silently Max's happiness with the Grace family on the beach and also his agony at losing both his first love and his wife. However, it is just an on-looker. What happens, sad or happy, cannot change it at all. It remains a cool observer, taking all with its rising and falling.

Nature is home to mankind-home to the soul in all its purity and holiness. In Greek mythology, man can change into a plant, implying the philosophy that man can live in harmony with nature. Greek philosopher Zeno stated that the goal of life is "to live in agreement" or "live in harmony with nature".[8] In his fiction, Banville obviously shares the same philosophy as Zeno. He pursues his romantic quest for a spiritual home in nature. He holds that nature is the dwelling place of man's soul, where human beings can find consolation and be true to themselves.

\section{Imagination}

Banville pursues a romantic quest for mankind's ultimate spiritual home and it is nature that he turns to. Nature provides for man a shelter from the anxiety brought about by modern society and it can have a healing power, curing people of pains and traumas. However, it does not present itself clearly before man. It is imagination that helps people understand and get closer to nature.

Imagination is the ability to form mental images, or the ability to spontaneously generate images within one's own mind. It is considered to be the supreme faculty of the mind by Romantics. It is extolled as the ultimate synthesizing faculty, enabling humans to reconcile differences and opposites in the world and is also mankind's ultimate shaping or creative power. However, for a long time in literary history, the ability to imagine has been despised by the theory of imitation. It was not until the $18^{\text {th }}$ century that imagination was valued again. William Wordsworth was one of the Romantic poets most intent on interpreting, defining and exploring the imagination. For him, imagination was a supreme gift which he used as a synonym for "intuition" and with which he associated the creative power of the poetic principle. He believed that the power of imagination can save people from the dominance of rationalism and utilitarianism, from the yoke of materialism and technocracy. Kant's statement that the imagination "is a powerful agent for creating, as it were, a second nature out of the material supplied to it by actual nature," is echoed in Coleridge's claim to the imagination as "a repetition in the 
finite mind of the eternal act of creation in the infinite I Am"[9] According to Romantic thoughts, without an active imagination a person can never understand or really appreciate his surroundings. Imagination plays such an important role in Romanticism that it is often viewed as the defining way for mankind to understand nature.

Banville obviously shares the same view on the significance of imagination with Romantics. In an interview, he claimed that "in a fallen world, a world which has been abandoned, or been abandoned by, God, humanity is left to its own imaginative devices." [10] A notable Romantic feature of Banville's works is their soaring imagination and fantasy. In his science tetralogy, Dr Copernicus, Kepler, The Newton Letter and Mefisto, Banville represents certain facts and figures, from the likes of such historical figures as Kepler, Copernicus and Newton as if they were actually real. Also in the apparently fictional art trilogy, historical facts are actually represented there. The Book of Evidence draws on an actual murder in Dublin some twenty years ago and Athena fictionalises the famous art robbery from Russborough House in 1986. However, what Banville writes about are not historical facts or historical figures and his novels are far from biographies. He once said in an article that his goal was not only to "portray the men and their times", but also "to illustrate something of their ideas by an orchestration of formal movement and rhythm in the prose."[11] Therefore, The Book of Evidence "completes Banville's vision of a de-centered universe in which humanity protects and consoles itself through a fantastical, if fractured, imagination."[7]

Banville fully applies his imagination in his novels, creating different images of scientists and artists from the stereotypes in historical texts. As Joseph McMinn once said, "every fiction by Banville may be seen as a poetic analogy for the conflict between versions of reason and imagination."[7] Banvillean characters invariably realize in the end that what they have been trying to create and project by reason is necessarily a fake because it is based upon language and all that language can offer is a distorted image of the world. Therefore, to break through the confines of words, Banville calls for an appreciation the world, nature or the universe through our imagination as it is a fundamental faculty through which people make sense of the world. His science tetralogy and art trilogy are dominated by intellectual figures who, having pursued the truth of the universe or the meaning of life, invariably fail. They finally have to attribute their failure to the failure of their imagination. In The Book of Evidence, Freddie Montgomery confesses to readers that "failure of imagination" is his real crime, "the one that made others possible."[12] In its sequel, Ghost, Banville has said that he imagines Freddie inhabiting purgatory and is thus caught between the living and the dead, imagination and reality.[13] And Freddie's crime is also a failure of imagination; he must use the powers of imagination to try and put everything right. His vivid imagination is both his curse and his only possibility of salvation since imagination can free mankind from materialism and reason and lead man into harmony with nature.

Banville applies imagination fully in his description when comparing an intangible sense with a tangible thing. For instance, Cleave says in Eclipse that "I have a deep dislike of mornings, their muffled musty texture, like that of a bed too long slept in."[3] The sentence gives a vivid feeling of morning, turning it from the untouchable to touchable with comparison to a bed, together with using vivid adjectives such as muffled and musty.

Banville realizes the importance of imagination and uses an essential component of imagination in art, that of memory, to convey his characters' imaginative ability. The importance of memory in imagination can be seen from the following passage of Nabokov:

"The simultaneousness of these random events, and indeed the fact of their occurring at all as described by the central percipient, would only then conform to 'reality' if he has at his disposal apparatus to reproduce those events optically within the frame of the screen; but the central figure... is not equipped with any kind of video attached to his lawn chair and must therefore rely on the power of pure imagination - hence my inverted commas around 'reality'. Whatever the mind grasps, it does so with the assistance of creative fancy, and drop of water on a glass slide which gives distinctness and relief to the observed organism."'[14]

What Nabokov suggests is the imaginative nature of the act of remembrance, an idea that Banville seems to share. As mentioned above, Banville is adept at depicting intangible senses. However, the charm of the sense depiction lies not in the vividness of the depiction of sense itself but in its relation with other psychological activities. In Banville's works, the reminiscence of the past is always provoked by senses:

Just now, I caught myself at it again, that thin, wintry whistling through the front teeth that I have begun to do recently. Deedle deedle deedle, it goes, like a dentist's drill. My father used to whistle like that, am I turning into him? [4]

Morden in The Sea remembers his father through the sounds he made with his teeth. It is the sound that relates the present with the past: "It was the smell, I am convinced, of what was, is wrong with her. It is not at all extraordinary, just a dull flat grey faint stink, like that of unwashable hair, or a garment left in the draw and gone stale." [3] So the narrator Cleave is able to have recollections of his dead uncle through the smell of his daughter: it is smell that functions as the link.

The narrator, then, can remember the past from the sight of a stranger (vision), the flavour of a dinner (taste), 
or the feeling of the bed sheet (touch). His practice reminds the readers of the theories of modern psychologists. As William James once pointed out: sometimes a tune, a flavor, a taste can arouse a familiar but ineffable feeling, which drives deeply into our consciousness and shocks us with its mysterious power. And Bergson also mentions that when he smells the scent of roses, many childhood memories come flooding back to him all at once and he can smell the past through the scent of the roses. Furthermore modern psychologists prove that current feelings can bring to mind past feelings and also unconscious feelings below the sensation threshold.[15] Through these sensation threshold, the present can be linked with the past as long as there is a similarity in the present and the past.

\section{Conclusions}

Through fiction Banville explores three ways of escaping from the chaotic world and freeing oneself from alienation. These ways have one trait in common, which is, escape: escape from the present to the past, from the industrial world to the natural world, from material things to imaginary ones. Though Banvillean characters suffer from bitterness because of their escape, they eventually find a spiritual home. Moreover, the utopian world created by Banville for his protagonists, cannot solve all problems in reality. However, it provides an ideal, a belief towards a sublimate life, which helps mankind bravely face the real world and provides hope. Like Oscar Wilde, W. B. Yeats and James Joyce, Banville imagines a better world in his fiction; and if imagined, this world might in time actually come to be. Such imagining is an ongoing project in which Banville is fully engaged. As he once said in an interview, "we do love a dreamer,"[16] he himself is a dreamer.

Banville shares the belief of modernist writers that the modern society alienates mankind through its chaos, madness and sterility, but denies the fatalist idea that this society is hopelessly doomed. At the end of his stories, the characters usually come to a sudden epiphany of the meaning of life or the universe, which implies hope and faith rather than despair and desperation. Can man find his spiritual home? Banville gives readers his answer in his writing.

\section{REFERENCES}

[1] O'Donohue, John. "An Interview". The Reviewer, 1990(Dec, 8). p. 24.

[2] Palazzolo, Pietra. The Literary Encyclopedia: Postwar and Contemporary English Writing and Culture, 1945-present. London: Gaskell Press, 1990. p. 1164.

[3] Banville, John. Eclipse. New York: Vintage Books, 2002.p. $87,4,4,5,49,123,67,27,72$.

[4] Banville, John. The Sea. London: Picador, 2005. p. 13, 99, $73,24,158,1,8$.

[5] Bakhtin, M. M. The Dialogic Imagination: Four Essays. trans. Michael Holquist. Austin: University of Texas Press, 1881. p. 147.

[6] Banville, John. Birchwood. London: Gaskell Press, 1991.p. 37.

[7] McMinn, Joseph. The Supreme Fictions of John Banville. New York: Manchester University Press, 1999. p. 36, 115, 9.

[8] Drozdek, Adam. Greek Philosophers as Theologians: The Divine Arche. London: Routledge, 2016, p. 242.

[9] Hancock, Stephen. The Romantic Sublime and Middle-Class Subjectivity in the Victorian Novel. New York: Routledge, 2005, p. 50.

[10] Banville, John. "Waiting for the Last Word". The Observer, 1989 (Dec, 31). p 36.

[11] Banville, John. "Physics and Fiction: Order from Chaos". New York Times Book Review, 1985 (April, 21). p. 42.

[12] Banville, John. The Book of Evidence. London: Picador, 2010. p. 142.

[13] Schwall, Hedwig. "An Interview with John Banville”. The European English Messenger, 1997(1). P.36-37.

[14] Nabokov, Vladimir. Strong Opinions. New York: McGraw-Hill Book Company, 1973. p. 154.

[15] Friedman, Melvin. Stream of Consciousness: A Study in Literary Method. Connecticut: New Haven, 1955. p. 246.

[16] Banville, John. "The Day a Poker Poked a Hole in Modern Thinking: A Review of Wittgenstein's Poker by David Edmonds". The Irish Times, 2001 (May, 26). p. 35. 